\title{
MATRIMONIAL FINANCE CONSEQUENT ON DIVORCE: THE ENGLISH STRUCTURE*
}

\author{
JOSEPH JACKSON, Q.C.**
}

The Matrimonial Proceedings and Property Act 1970 (U.K.) made considerable changes to the English law of matrimonial finance. Joseph Jackson reviews the historical background and recent developments with respect to the Act and discusses the effect of this legislation on the courts determination of the financial consequences of divorce. The relevant case law is examined and comments of the English Law Commission are summarized.

The financial consequences to the spouses of the breakdown of marriage are clearly of the utmost importance to them. To the emotional problems inherent in such a situation is added the insecurity which each of them will inevitably feel in regard to where and how they will manage in the future. The woman will worry about what accommodation and income will be available to her and to any children in her care, and the man will be concerned about the possible burden of supporting two units in place of one, particularly when he has in mind the establishment of a new family with another wife.

This is the basic situation as an English lawyer would see it, and the variety of problems arising from it is as endless as the peculiarity of facts emanating from breakdown of the union of two people who are real and individual before they merge into and become mere statistics. Moreover, there is a host of different approaches to the legal structure which governs in these situations. They vary from community of property (i.e. some division of some or all of the assets of both spouses) coupled perhaps with income provision, to a mere return to the woman of a sum of money stipulated in a marriage contract with no further financial liability to her thereafter (a Moslem situation).'

The English approach (England for these purposes includes Wales) is once more under consideration. A recent discussion paper of the English Law Commission has provided a valuable analysis of the differing schools of thought about the financial consequences of divorce. ${ }^{2}$ As that paper observes, one cannot appreciate the present state of the relevant English law and the debate concerning it without an understanding of the historical background. ${ }^{3}$

Judicial divorce was introduced into English law by the Matrimonial Causes Act 1857.' Before that Act there was a system of parliamentary

* This paper was presented as the Weir Memorial Lecture, delivered at the Faculty of Law at the University of Alberta on September 23, 1981.

** M.A., LL.B. (Cantab.), LL.M. (Lond.), Bencher of the Middle Temple, Chairman of the Family Law Bar Association. Joseph Jackson is the author of The Formation and Annulment of Marriage, Matrimonial Finance and Taxation and editor of Rayden on Divorce.

1. California has one system of community law.For the return of dower, see Quaziv.Quazi [1980] A.C.744 (H.L.); Qureshi v. Qureshi [1972] Fam.173.

2. Law Com. No. $103(1980)$.

3. Id. paragraph 8. The statutes from 1857 onwards are printed in Rayden's Law and Practice in Divorce and Family Matters (13th ed. Joseph Jackson ed. 1979); see Chapter 1 for the historical background. See also Joseph Jackson. The Formation and Annulment of Marriage (2nd ed. 1969).

4. $20 \& 21$ Victoria c. 85 . 
divorce which was very rare and very expensive. The grounds introduced by statute were founded on guilt or, in the modern parlance, fault, and there was no automatic right to a divorce even if the appropriate grounds were established. For a male petitioner it sufficed to prove adultery but a woman had to prove adultery and some other offence such as cruelty or desertion. Collusion, connivance and condonation were absolute statutory bars to divorce; the petitioner's own adultery could also be a bar, as could delay in the presentation of the case.

The financial relief afforded by the Matrimonial Causes Act 1857 was limited. It was confined to periodical payments for the woman's life secured on property provided by her husband. That property did not pass to the woman; it guaranteed the payments and ultimately reverted to the husband or to his estate. This remedy suggests that divorce was for those of substance. There was no provision for varying these orders. No such order could be made against a woman. The only other financial remedy in the Act of 1857 was that a guilty wife's property might be taken from her and settled on the husband and the children; this was a punishment for misconduct, founded presumably on the reasoning that a wife who was irresponsible sexually was also irresponsible financially, and moreover, she should not be allowed to take her money to another man. Shortly after the Act of 1857, a statute of 1859 provided for the variation of marriage settlements. Marriage settlements are now out of fashion, but again one can see emphasis on people with property. Divorce was not for the ordinary plebeians. But the non-propertied plebeians intruded into the Divorce Court, and this is reflected in the preamble to the Matrimonial Causes Act 1866. It provided: ${ }^{5}$

And whereas it sometimes happens that a decree for a dissolution of marriage is obtained against a husband who has no property on which the payment of any [such gross or annual] sum can be secured, but nevertheless he would be able to make a monthly or weekly payment to the wife during their joint lives; be it therefore enacted... .

There then followed a provision for ordinary unsecured periodical payments for the joint lives of the parties: if the wife who received such an order survived her husband she would be without the protection of a secured periodical payments order which would have lasted for her life. She could have both types of order. Eventually the court was given power to vary orders for unsecured periodical payments for joint lives, but it was not until 1949, 92 years after the first Matrimonial Causes Act, that the court was given power to vary secured periodical payments for the life of the wife.

In 1963 the court was given power to award lump sums by a statute ${ }^{6}$ that also took the teeth out of the bars to divorce, making divorce more or less consensual in practice though not so in law. No guidance was given as to how lump sums were to be calculated; it was left to the discretion of the court.

What was the philosophy that governed the original (1857) legislation? Its understanding is important because it left its mark heavily on what followed, and today it is still felt in the law and practice in this emotional and important field.

5. 28 \& 29 Victoria c. 32 .

6. Matrimonial Causes Act 1963 (U.K.), c. 45, s. 5. 
The legislators of 1857 looked at the law in this way. Marriage was for life, and spouses were expected to adhere to this principle and to regard divorce as a disaster imposed on one of them by the disgraceful behaviour of the other. When a marriage took place the wife obtained a common law right to be maintained for life by her husband. That common law right was terminated on divorce. Assuming that she was the petitioner and her husband the guilty party, simple justice required her to be compensated for the loss of her lifelong right to maintenance by putting her in the financial position in which she would have been if the marriage had continued and had not been destroyed by the husband's breach of his matrimonial duties.

Hence the first Matrimonial Causes Act provided for secured provision for life. There was no thought of variation of orders (they were happily immune from the ravages of inflation) and the notion was to buttress the institution of marriage by making it clear to a man who had behaved so badly as to justify divorce that by so doing he could not shake off his lifelong liability to his erstwhile wife. Lifelong meant lifelong: the liability did not terminate on the wife's remarriage or on the husband's death. It was for her life, though the later power to vary orders meant that on the wife's remarriage the amount paid to her might decrease or be merely nominal. If the wife's remarriage failed, she might have orders against two former husbands.

One can see the approach of the early courts by looking at a decision in 1865 (when only secured payments were possible) by the Judge Ordinary (Sir James Wilde, later Lord Penzance). He said this:?

\begin{abstract}
... The husband has of his own wrong and wickedness thrust forth his wife from the position of participator in his station and means... He has succeeded in shaking off the obligations of marriage, and that by his own voluntary breach of them. And if he can part with his wife at the door of the divorce court without any obligation to support her, and with full liberty to form a new connection, his triumph over the sacred permanence of marriage will have been complete. To him marriage would have been a mere temporary arrangement, conterminous with his inclinations, and void of all lasting tie or burden. To such a man the Courts may truly say with propriety, "according to your ability you must still support the woman you have first chosen and then discarded. If you are relieved from your matrimonial vows it is for the protection of the woman you have injured, and not for your own sake. And so much of the duty of a husband as consists in the maintenance of his wife may be justly kept alive and en forced upon you in favour of her whom you have driven to relinquish your name and home". If this be to give the wife a pecuniary interest in obtaining a divorce, it is also to hold a pecuniary penalty over the head of the husband for the observance of married duty. And if it be wise to repress divorce, it is still wiser to go a step higher and repress that conduct which makes divorce possible. It is the foremost duty of this Court in dispensing the remedy of divorce to uphold the institution of marriage. The possibility of freedom begets the desire to be set free, and the great evil of a marriage dissolved is, that it loosens the bonds of so many others. The powers of this Court will be turned to good account if, while meting out justice to the parties, such order should be taken in the matter as to stay and quench this desire and repress this evil. Those for whom shame has no dread, honourable vows no tie, and violence to the weak no sense of degradation, may still be held in check by an appeal to their love of money; and I wish to be understood that. so far as the powers conferred by the section go, no man should. in my judgment, be permitted to rid himself of his wife by ill-treatment, and at the same time escape the obligation of supporting her. I only regret that the machinery created by the statute is not entirely suited to the circumstances of those who, with a sufficient income from their labour, have yet no realized property.
\end{abstract}

So conduct - or, to be more accurate, misconduct - was emphasized from the start. And the State had an interest in financial awards.

The corollary of this approach was that a wife whose husband divorced her because of her misbehaviour was not entitled to be maintained by him at all because of her fundamental breach of her matrimonial obligations to

7. Sidney v. Sidney (1865) 4 Sw. and Tr. 178 at $180,181$. 
him. In course of time the courts developed the notion of what was termed a "compassionate allowance" for a wrongdoing wife, but it can be seen at once that a wife might well be driven to resist charges made against her with all the force at her command in order not to be left without any support whatsoever. In many cases she would be compelled to fight whether or not she wanted a divorce, so as not to be left destitute on the basis that, as the wrongdoer, she was not entitled to maintenance from her husband. Although modified in practice with the passage of years, that was the underlying situation which prevailed until the dramatic changes effected by the Divorce Reform Act $1969^{8}$ and the Matrimonial Proceedings and Property Act $1970,{ }^{9}$ statutes now consolidated in the Matrimonial Causes Act $1973 .{ }^{10}$

One last historical point merits mention. At common law a wife's property was controlled by her husband. In 1882 the Married Women's Property Act" introduced a procedure available to either husband or wife. That remedy relates to any question between husband and wife as to title to or possession of property. It is not a discretionary jurisdiction. It decides who owns what, not to whom property shall be given. It may be resorted to independently of divorce. Thus a wife can seek an order for her property by means of a very simple procedure.

The Divorce Reform Act 1969 changed the structure of divorce. The sole ground thereafter was to be, and is, irretrievable breakdown of marriage, but to establish breakdown a petitioner has to prove one of five "facts": adultery, behaviour by the respondent such that the petitioner cannot reasonably be expected to live with him or her, desertion for two years, separation for two years with consent of the respondent to the divorce, or five years' separaton without the respondent's consent to the divorce. ${ }^{12}$ So that Act has three inbuilt philosophies: fault, consent and unilateral divorce.

Contrary to the assertions of the proponents of the Divorce Reform Act 1969 , the number of divorces has vastly increased since the passage of the Act. In rough terms it has gone up from what was then considered to be high at 70,000 a year to 170,000 a year.

The Matrimonial Proceedings and Property Act $1970^{13}$ made considerable changes to the law of matrimonial finance. It entitles either spouse to apply for financial orders. The scope of these orders has been enlarged. They divide into two categories, known as financial provision and property adjustment orders. Financial provision consists of periodical payments for joint lives, secured provision for the life of the payee, and lump sum or sums. Property adjustment orders consist of transfer of property, settlement of property, and variation of nuptial settlements. The division is not logical; lump sums are a capital adjustment and more akin to property adjustment than to periodical payments. The Act also provides that periodical payment orders should automatically cease on remarriage of the payee, and, as a corollary, applications for

8. Divorce Reform Act 1969 (U.K.), c. 55.

9. Matrimonial Proceedings and Property Act 1970 (U.K.), c. 45.

10. Matrimonial Causes Act 1973 (U.K.), c. 18.

11. $45 \& 46$ Victoria c. 75 .

12. Supra n. 8, s. 2.

13. Supra n. 9. 
financial provision or property adjustment orders cannot be instituted once a remarriage of the would-be claimant has taken place. However, a claim made before remarriage for a lump sum or property adjustment order may be continued thereafter; how that remarriage is taken into account is not easy to ascertain from the cases.

The Act thus contains new powers, the power to order transfers of specific property and to order property to be settled. It also for the first time contains specific guidelines as to how the court is to exercise its powers. Hitherto the legislation had simply enacted that the court must make such awards as are just, and the court had made its own rules and guidelines. The new statutory guidelines are of the utmost significance. Section 5 of the Act of 1970, now re-enacted as s. 25 of the Matrimonial Causes Act 1973 (to be compared with section 8 of the Alberta Matrimonial Property Act) provides:

It shall be the duty of the Court in deciding whether to exercise its powers . . . in relation to a party to the marriage and, if so, in what manner, to have regard to all the circumstances of the case including the following matters, that is to say -

(a) the income, earning capacity, property and other financial resources which each of the parties to the marriage has or is likely to have in the foreseeable future:

(b) the financial needs, obligations and responsibilities which each of the parties to the marriage has or is likely to have in the foreseeable future:

(c) the standard of living enjoyed by the family before the breakdown of the marriage:

(d) the age of each party to the marriage and the duration of the marriage;

(e) any physical or mental disability of either of the parties to the marriage;

(f) the contributions made by each of the parties to the welfare of the family, including any contribution made by looking after the home or caring for the family;

(g) in the case of proceedings for divorce or nullity of marriage, the value to eit her of the parties to the marriage of any benefit (for example, a pension) which, by reason of the dissolution or annulment of the marriage, that party will lose the chance of acquiring:

and so to exercise those powers as to place the parties, so far as it is practicable and, having regard to their conduct. just to do so, in the financial position in which they would have been if the mar. riage had not broken down and each had properly discharged his or her financial obligations and responsibilities towards the other.

The legislature obviously was not satisfied with a simple reference to "all the circumstances of the case" but added specific matters, all of them taken from previously decided cases, including the homily at the end "and so to exercise those powers etc.". This exhortation was described by one judge as "an elusive concept based on a difficult hypothesis". ${ }^{14}$ In the vast majority of cases it is not possible to put the parties in the financial position in which they would have been if the marriage had not broken down, even if one could satisfactorily work out what that situation would have amounted to had the marriage survived. "So far as it is practicable" is an important qualification, and what does "having regard to their conduct" signify?

How were the Act of 1970 and in particular the guidelines to be interpreted? At first the Court of Appeal decided that the statute was "obviously intended to codify the existing law and practice". ${ }^{15}$

Under the existing law and practice, claims for periodical payments had been founded on a one-third approach, but this was very flexible depending on the circumstances of the case before the court. "One third" meant one-third of the joint incomes of the parties. On the whole wives had not been expected to work, and the liability to children did not affect

14. Harnett v. Harnett [1973] Fam. 156 at 161.

15. Ackerman v. Ackerman [1972] Fam. 225 at 232 (C.A.). 
the wife's claims in her own right. As for lump sums, the power to award these being introduced in 1963, the first case in 1967 went to the Court of Appeal where the wife's lump sum award was increased to $£ 25,000$, the husband having not less than $£ 400,000$; she also had periodical and secured payments awarded to her. ${ }^{16}$ The cases on lump sums were not numerous, and no coherent principles could be established from them. The Court of Appeal was generous to say of those cases: ${ }^{17}$

"They will be found usefully set out in Mr. Joseph Jackson's chapter on the subject in his book on 'Matrimonial Finance and Taxation' (1972), pages 116 to 131. The circumstances are so various that few general principles can be stated. One thing is, however, obvious. No order should be made for a fump sum unless the husband has capital assets out of which to pay it - without crippling his earning power"

That citation is taken from Wachtel $\mathrm{v}$. Wachtel. This case is considered by some to be the high watermark in wives' financial claims, but the harsh reality is that for the wife in that case it was a defeat in the Court of Appeal. The trial Judge had awarded her one-half of the sole capital asset owned by the parties, the matrimonial home. ${ }^{18}$ The Court of Appeal reduced that award.

The judgment of the Court of Appeal in Wachtel v. Wachtel, delivered by Lord Denning M.R. (a judgment which contrived not to follow the previous decision of the Court of Appeal), led the way in two particular aspects, one in relation to conduct, one in relation to division of assets and award of maintenance. But Wachtel has some affinity with the Bible: in it may be found a text for nearly all propositions, but as with all wondrous things, not everyone interprets what they see in quite the same way. Indeed, some still regard Wachtel as the New Testament, and some as the Old, and as with many a Testament, some have allowed dust to settle on it and revert to the statute. When all else has failed, read the instructions!

There are two particularly relevant passages in the case, which need to be cited in full. The first reads as follows: ${ }^{19}$

The conduct of the parties

When Parliament in 1857 introduced divorce by the Courts of law, they based it on the doctrine of the matrimonial offence. This affected all that followed. If a person was the guilty party in a divorce suit, it went hard with him or her. It affected so many things. The custody of the children depended on ward of maintenance. To say nothing of the standing in society. So serious were the consequences that divorce suits were contested at great length and at much cost.

All that is altered. Parliament has decreed: 'If the marriage has broken down irretrievably, let there be a divorce'. It carries no stigma, but only sympathy. It is a misfortune which befalls both. No longer is one guilty and the other innocent. No longer are there long contested divorces. Nearly every case goes uncontested. The parties come to an agreement, if they can, on the things that matter so much to them. They divide up the furniture. They arrange the custody of the children, the financial provision for the wife, and the future of the matrimonial home. If they cannot agree, then matters are referred to a Judge in Chambers.

When the Judge comes to decide these questions, what place has conduct in it? Parliament still says that the Court has to have "regard to their conduct"... Does this mean that the Judge in Chambers is to hear their mutual recriminations and to go into their petty squabbles for days on end, as he used to do in the old days? Does it mean that, after a marriage has been dissolved, there is to be a post mortem to find out what killed it? We do not think so. In most cases both parties are to blame - or, as we would prefer to say - both parties have contributed to the breakdown.

It has been suggested that there should be a "discount" or "reduction" in what the wife is to receive because of her suppposed misconduct, guilt or blame (whatever word is used). We cannot accept this argument. In the vast majority of cases it is repugnant to the principles underlying the new

16. Davis v. Davis [1967] P. 185 (C.A.).

17. Wachtel v. Wachtel [1973] Fam. 72 at 95 (C.A.).

18. Id. at 81 .

19. Id. at 89 . 
legislation, and in particular the Act of 1969. There will be many cases in which a wife (though once considered guilty or blameworthy) will have cared for the home and looked after the family for very many years. Is she to be deprived of the benefit otherwise to be accorded her ... because she may share responsibility for the breakdown with her husband? There will no doubt be a residue of cases where the conduct of one of the parties is in the Judge's words "both obvious and gross", so much so that to order one party to support another whose conduct falls into this category is repug. nant to anyone's sense of justice. In such a case the Court remains free to decline to afford financial support or to reduce the support which it would otherwise have ordered. But, short of cases falling into this category, the Court should not reduce its order for financial provision merely because of what was formerly regarded as guilt or blame. To do so would be to impose a fine for supposed misbehaviour in the course of an unhappy married life. Counsel disputed this and claimed that it was but justice that a wife should suffer for her supposed misbehaviour. We do not agree. Criminal justice often requires the imposition of financial and indeed custodial penalties. But in the financial adjustments consequent upon the dissolution of a marriage which has irretrievably broken down. the imposition of financial penalties ought seldom to find a place.

This attitude to conduct was, of course, entirely novel, to say the least, but it has since prevailed, not without dissatisfaction in some quarters. The key phrase is "obvious and gross", to which we shall return.

The second passage from Wachtel is as follows: ${ }^{20}$

The one-third rule.

In awarding maintenance the Divorce Courts followed a practice of the ecclesiastical Courts. They awarded an innocent wife a sum equal to one-third of their joint incomes. Out of it she had to provide for her own accommodation, her food and clothes, and other expenses. If she had any rights in the matrimonial home, or was allowed to be in occupation of it, that went in reduction of maintenance. There was, we think, much good sense in taking one-third as a starting point. When a marriage breaks up there will thenceforward be two households instead of one. The husband will have to go out to work all day and must get some woman to look after the house - either a wife, if he remarries, or a housekeeper, if he does not. He will also have to provide maintenance for the children. The wife will not usually have so much expense. She may go out to work herself, but she will not usually employ a housekeeper. She will do most of her housework herself, perhaps with some help. Or she may remarry, in which case her new husband will provide for her. In any case. when there are two households, the greater expense will, in most cases, fall on the husband than the wife. As a start has to be made somewhere, it seems to us that in the past it was quite fair to start with one-third. ... This so-called rule is not a rule and must never be so regarded. In any calculation the Court has to have a starting point. If it is not to be one-third, should it be one-half or one-quarter? A starting point at one-third of the combined resources of the parties is as good and rational a starting point as any other, remembering that the essence of the legislation is to secure flexibility to meet the justice of particular cases and not rigidity, forcing particular cases to be fitted into some so-called principle within which they do not easily lie. There may be cases where more than one-third is right. There are likely to be many others where less than one-third is the only practicable solution. But one-third as a flexible starting point is in general more likely to lead to the correct final result than a starting point of equality, or a quarter ....

Under the new dispensation, she will get a share of the capital assets; and, with that share, she will be able to provide accommodation for herself, or, at any rate, the money to go some way towards it....

In these days of rising house prices, she should certainly have a share in the capital asset which she has helped to create. The windfall should not all go to the husband. But we do not think it should be as much as one-half, if she is also to get periodical payments for her maintenance and support. Giving it the best consideration we can, we think that the fairest way is to start with one-third of each. If she has one-third of the family assets as her own - and one-third of the joint earnings her past cont ributions are adequately recognised, and her fut ure living standards assured so far as may be. She will certainly in this way be as well off as if the capital assets were divided equally which is all that a partner is entitled $t o$.

We would emphasise that this proposal is not a rule. It is only a starting point. It will serve in cases where the marriage has lasted for many years and the wife has been in the home bringing up the children. It may not be applicable when the marriage has lasted only a short time, or where there are no children and she could go out to work.

This was a revoluntionary approach to the division of resources.

After Wachtel the courts have had to ignore conduct to a very large extent, though there are a number of cases explaining conduct that is "ob-

20. Id. at 94 . 
vious and gross". One case ${ }^{21}$ where the wife shot at her husband, inflicting a mild injury, did not result in a complete reduction in the wife's claim: she got one-quarter instead of a third of the assets. (Had she been a better shot, there would, of course, have been no case.) Inflicting wounds twice of considerable gravity on a husband did result in reduced orders in another case. ${ }^{22}$ Adultery in itself is almost always not a reducing factor. Although there is one remarkable reported case to the contrary, ${ }^{23}$ usually adultery does not diminish a claim, even in circumstances which might formerly have been termed reprehensible, as for example in the case of the woman who had what the judge described as "a ridiculous affair with a youth half her age to whom the parties had given occasional hospitality when he was a schoolboy and his parents were abroad ..." ${ }^{24}$ Adultery by a man with a daughter-in-law was "shocking" and "disgraceful" but had no financial effect. ${ }^{25}$

In relation to the division of assets, the one-third approach as to capital was, as already stated, novel. The case which introduced it, Wachtel, was decided in February 1973 when the country and the world were seemingly prosperous, when house prices and the stock exchange were booming, and the Yom Kippur war and oil prices had not yet disturbed the world's economy. The "windfall", using the terminology of the case, was to be for the benefit of both parties.

In subsequent years, when the English economy was not so flourishing, a number of cases emphasised the difficulties. Indeed, areas of particular difficulty abound, and some are here chosen for particular reference, but one must emphasise that the ratio underlying continuing support for a former spouse who does not remarry is the liability to maintain that spouse at least for joint lives if not for her (or his) life. That was the ratio established in 1857.

There is dissatisfaction expressed with the 1969 and 1970 legislation which came after Law Commission Reports. The Law Commission might well say, as did the Irishman when a stranger asked him the way, "If I were going there, I would not start from here."

To the difficulties:

(1) Where the only asset is the home, the court might well not order a sale and a share out of the proceeds to take place in the near future if to do so would mean that the spouse with care and control of the children would not be able to re-house herself (or himself) with whatever was her (or his) share. The courts sometimes give the whole house to the spouse having the care of the children with much smaller periodical payments (if any) than would otherwise be justified, but more often the courts in such circumstances have given the wife (and sometimes the husband) the right to stay in the house until the youngest child's education is completed, or some other such terminating event, with an order for dividing the property when that event occurs. These settlement orders, introduced by a

\footnotetext{
21. Armstrong v. Armstrong (1974) 118 Sol. Jo. 579 (C.A.).

22. Bateman v. Bateman [1979] Fam. 25.

23. Cuzner v. Underdown [1974] 2 All E.R. 351 (C.A.).

24. Harnett v. Harnett, supra n. 14 at 166.

25. Dixon v. Dixon (1975) 5 Fam. Law 58 (C.A.).
} 
case decided in the Court of Appeal in $1973,{ }^{26}$ are now coming home to roost, in the sense that the one-half or one-third or whatever that accrues to the wife on the terminating event is often not enough adequately to rehouse her.

(2) A wife's earning capacity is clearly a relevant factor in assessing her needs, but in a period of recession and high unemployment the wife's ability to find work is reduced, and this places a burden on both former spouses.

(3) Husbands who remarry and have to keep a former family are often financially unable to do so and keep themselves and a new family at a reasonable standard, and this causes much resentment, particularly in the case of second wives whose assets and earning powers may in a sense be used to keep the first wife and family.

(4) While the 1970 Act enacted that remarriage ends the wife's claims to periodical payments, cohabitation with another man does not. In the case of cohabitation it is purely a question of what financial benefit, if any, the former wife gets from such cohabitation or association. ${ }^{27}$ These factors may and often do cause much resentment.

(5) The House of Lords has approved of the so-called "clean break principle" whereby, on the basis of capital provision for the wife, her claims may be dismissed once and for all. ${ }^{28}$ In theory and often in practice this procedure has much to recommend it, but sometimes it may simply result in the State having to support the former wife. A clean break may only be achieved by the court dismissing the spouse's claims for periodic payments and secured periodical payments, and the claimant spouse has to agree to such dismissal. ${ }^{29}$ In the case of lump sums and property adjustment orders, the court can only effectively make one order and this may be for whatever the court thinks right or, more usually, for whatever the parties agree. In broad terms, once there is such an order for a capital provision, or the claims (in whatever guise) for capital have been dismissed, no further capital order may be obtained. There are also provisions enabling a former spouse who has not remarried to make financial claims against the estate of a deceased former spouse, but there is jurisdiction at the time of divorce for the parties by consent to obtain an order, with the court's approval, that they shall not be entitled on the death of the other to present inheritance claims. ${ }^{30}$

(6) Loss of pension rights by a former wife is referred to specifically in the statute, but often there is no practical way of compensating her for the loss of such rights which terminate on divorce. She can never be a widow - a usual qualifying status for a pension - because she has ceased to be the wife, and it is on the death of the former husband and the cessation of his income that acute problems may arise.

(7) The costs of litigation may be considerable, recourse being had not only to lawyers but also to accountants and valuers. Every legal step and every day in court reduces the resources available for distribution. Legal

26. Mesher v. Mesher Times (February 13, 1973) (C.A.), later reported fully at [1980] 1 All E.R. 126.

27. Miller v. Miller [1961] P. 1; Stead v. Stead [1962] P. 94 (Div. Ct.).

28. Minton v. Minton [1979] A.C. 593 (H.L.).

29. Dipper v. Dipper [1980] 2 All E.R. 722 (C.A.).

30. Inheritance (Provision for Family and Dependants) Act 1975 (U.K.), c. 63, s. 15. 
aid in England is extensive, and at one time the Legal Aid Fund would bear these costs for a party in receipt of legal aid, but now the costs come out of the property "recovered or preserved", with an exception as to the first $£ 2,500$. This situation obviously creates difficulties, ${ }^{31}$ particularly where the only real asset is the matrimonial home itself and the costs have to come out of that when it is sold.

(8) Men with interests in private companies or men having jobs with good perquisites can go on living at the standard of living that prevailed during the marriage without having the available resources to provide likewise for their former wives and families. This can sometimes be a galling situation when the children go from one home where money is tight to another home seemingly abounding in affluence.

(9) The converse situation appears to be true where a wife who has had a capital award takes it, as it were, to her new husband, and they with their combined wealth appear to live at a much higher standard than the former husband whose resources have been depleted by the award to his former wife.

(10) Cases are heard in Chambers, and few are reported. Appeals on quantum are difficult to establish in view of the discretionary power given to the Judge. There is some dissatisfaction with this situation.

(11) The one-third approach, particularly in relation to capital, is being heavily criticised. The statute makes no distinction between resources acquired after the marriage by the joint efforts of the parties and resources that existed before the marriage, or resources that are acquired by gift or inheritance, or resources that are acquired after the breakdown of the marriage and before the matrimonial financial case comes to court. We do not have the equivalent of $s .7$ of the Alberta Matrimonial Property Act; ${ }^{32}$ we have no "exempted" property. Nor do we have the equivalent of $s .8(f)$ which includes as a factor for the court's consideration "whether the property was acquired when the spouses were living separate and apart". ${ }^{33}$ In $O^{\prime} D$ v. $O^{\prime} D$ the Court of Appeal commented that Wachtel was $^{34}$

not typical of all the cases in which the court has to exercise its discretion. It was essentially a case of two people starting their married lives with little or nothing but their earning capacities, and together founding a family and building up by their joint efforts such capital as they were able to save. Typically, their main capital asset was the matrimonial home, bought on mortgage and paid for out of income.... In other cases the situation is different. One or other, or perhaps both, spouses may bring into the marriage substantial capital assets, or may acquire such assets during the marriage by inheritance or by gift from members of their families.... In these cases it is necessary to go directly to the terms of section 25 of the Act for guidance.

In $O^{\prime} D$ the total assets of the parties amounted to about $£ 215,000$, and the Judge had awarded the wife $£ 70,000$, which included the matrimonial home, and very small periodical payments. The Court of Appeal said that:

in cases on the scale of the present one this [one third] ratio may produce results which are, or may seem to be, ton high, but ipflation has already altered values very considerably, bringing many cases into the class in which the one-third rule would not have been accepted in the past.

So in the case of a millionaire one might not have a one-third approach, though there has been a recent case where about one-third was awarded

31. Hanlon v. The Law Society [1981] A.C. 124 (H.L.).

32. Matrimonial Property Act. R.S.A. 1980 c. M-9.

33. Id. s. 8(f).

34. $O^{\circ} D$ v. $O^{\prime} D[1976]$ Fam. 83 (C.A.). 
to the wife where she had made a substantial contribution to the build-up of the family resources. ${ }^{35}$ The largest sum awarded in court (much larger sums are agreed to out of court) was $£ 750,000$ in $E d g a r$ v. Edgar, although this sum was reduced on appeal to $£ 80,000$ because that was the sum the wife had agreed to take in a prior agreement held to be binding on her. ${ }^{36}$ Parties by common law, and now by statute,$^{37}$ cannot make an agreement that ousts the financial jurisdiction of the court - the State still has an interest in financial awards - but nevertheless, although the court has an overriding control over agreements, agreements are encouraged. It was said in Edgar v. Edgar: ${ }^{38}$

To decide what weight should be given, in order to reach a just result, to a prior agreement not to claim a lump sum, regard must be had to the conduct of both parties, leading up to the prior agree. ment, and to their subsequent conduct, in consequence of $i t$. It is not necessary in this connection to think in formal legal terms, such as misrepresentation or estoppel; all the circumstances as they affect each of two human beings must be considered in the complex relationship of marriage. So, the circumstances surrounding the making of the agreement are relevant. Undue pressure by one side, exploitation of a dominant position to secure an unreasonable advantage, inadequate knowledge, possibly bad legal advice, an important change of circumstances, unforeseen or overlooked at the time of making the agreement, are all relevant to the question of justice bet ween the parties. Important too is the general proposition that formal agreements, properly and fairly arrived at with competent legal advice, should not be displaced unless there are good and substan. tial grounds for concluding that an injustice will be done by holding the parties to the terms of their agreement. There may well be other considerations which affect the justice of the case; the above list is not intended to be an exclusive catalogue.

The Court in Edgar specifically held that an agreement not to claim a lump sum "should be taken into account under the heading of conduct". 39

(12) The interpretation in Wachtel that only "obvious and gross" conduct is relevant has met with the reaction that conduct should be taken into account on a broader basis than at present. Those who support the Wachtel approach assert with evident justification that to do so will in effect reintroduce the defended divorce case, which, apart from anything else, would involve a much increased expenditure on costs, thereby reducing the available assets for distribution among the parties, and so in effect being self-defeating. Those against the Wachtel approach say that simple justice - and the statute itself - require bad behaviour to be taken into account, and while costs are important they should not overwhelm the application of the law.

One can go on multiplying these difficulties and problems almost endlessly - and litigants do. The problems of the effect on awards of the duration of the marriage could occupy a full lecture, as could those involving valuations. One could spend much time on the eccentricities of income tax and capital gains tax. We have no equivalent of sections $9(3)(\mathrm{g})$ and 18(2) of the Alberta Matrimonial Property Act ${ }^{40}$ as to interest, and the English definition of matrimonial home ${ }^{41}$ is narrower than the Albertan. ${ }^{42}$ Dispositions to defeat claims is a feature of both jurisdictions, but the terms of such legislation vary considerably. But to generalise, wives

35. Preston v. Preston [1981] 3 W.L.R. 619 (C.A.).

36. Edgar v. Edgar [1980] 1 W.L.R. 1410 at 1417 (C.A.).

37. Hyman v. Hyman [1929] A.C. 601 (H.L.); Matrimonial Causes Act, supra n. 10. s. 34.

38. Edgar v. Edgar, supra n. 36 at 1417.

39. Id.

40. Matrimonial Property Act, supra n. 32, ss. 9(3) (g). 18(2).

41. Matrimonial Homes Act 1967 (U.K.), c. 75, as am.; Id., s. 1(c).

42. Matrimonial Property Act, supra n. 32, s. 1(c). 
think they get too little and husbands think they pay too much. Occasionally husbands make successful claims, but these are not the norm, not yet anyway. Why, ask the husbands, should wives get capital that they have not themselves earned? Why, ask the husbands, should marriage, which is plainly no longer for life, contain lifelong support obligations, particularly where a divorce is forced upon the husband who may, in the old sense, be the "innocent party"? How many orders in fact endure for life is not known, and perhaps in percentage terms is not as high as might appear at first sight, but for those who are subject to such orders the burden in the ordinary case may well be considerable. The problem is that one cannot extract and redistribute more than a pint from a pint pot even when it is full, and sometimes the pot is defieient in quantity for reasons varying from the understandable to the bad. This is no comfort to wives who have to resort to State support in whole or in part for their subsistence, whether because of the deficiency of the pot or whether because, as not infrequently occurs, enforcement of orders may prove difficult.

So, as the Law Commission points out in its discussion paper, ${ }^{43}$ there are arguments for change, and the paper lists the principal arguments as follows:

(1) Marriage is no longer a lifelong union and financial consequences of divorce should not be founded on the notion that it is.

(2) Since divorce is founded on irretrievable breakdown regardless of fault, the mere fact of divorce should no longer give an entitlement to maintenance.

(3) Lifelong support is impossible to attain in most cases.

(4) The changed economic role of women has rendered lifelong support of women out of date. sion:

The Law Commission puts forward various models of reform for discus-

(1) Retention of the guidelines of the Act as they now are.

(2) Retention of the guidelines without the direction at the end (putting the parties in the financial position they would have been in if the marriage had not broken down).

(3) The relief of need only.

(4) Rehabilitation only.

(5) The division of property once and for all, the "clean break".

(6) A fixed mathematical approach to all cases.

(7) Restoration of the parties to the position they would have been in had the marriage not broken down.

(8) A combination of some or all of these models.

Perhaps not surprisingly, the Law Commission itself makes no proposals and indeed expresses no tentative proposals for reform..$^{44}$

What appears to be the position to an English lawyer is that there can be no rules applicable to every case. Different cases require different considerations. Justice in this field cannot be confined. It has to adapt itself to all kinds of people and circumstances, to people of all ages, abilities and resources, and somehow extract a just situation for them all, or do the

43. Law Com. No. 103 (1980), Part III, 15.

44. Id. paragraph 91. It has done so since this lecture was delivered. 
best it can with the material at hand in the general economic situation then prevailing. There are never right answers, but in this context the converse of "right" is not "wrong" but possibly "not appealable" or "compromise". Perhaps we in England should go back to the simple old formula, that the court should make such awards as may be just, and do away with the so-called guidelines. We are, however, in the hands, as ever, of the politicians - the legislators - and what they will make of it all remains to be seen - and wondered at. 